
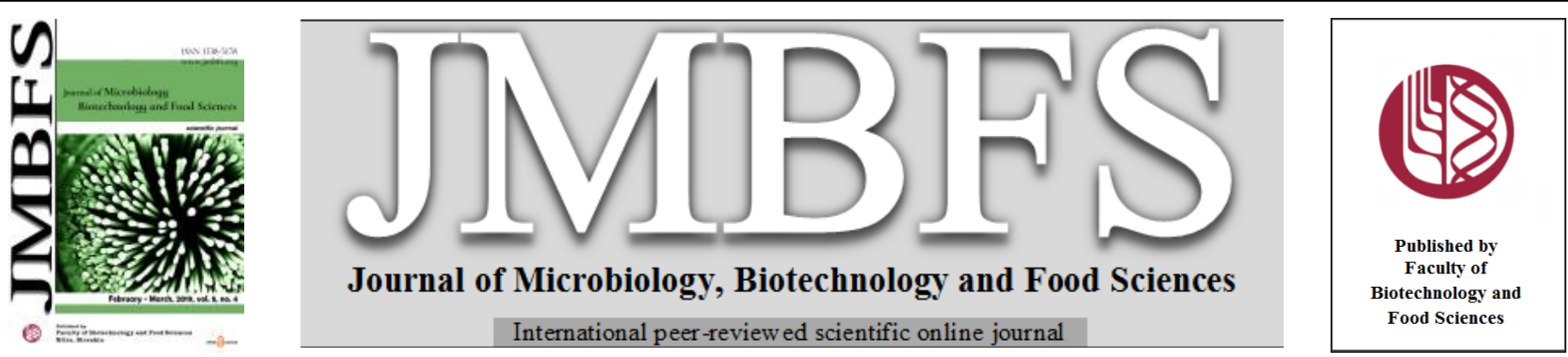

\title{
CONSTRUCTION OF PLANT TRANSFORMATION VECTOR CONTAINING EXPRESSION CASSETTE OF ARABIDOPSIS GENE At1g54410
}

\section{Eva Boszorádová*l, Mária Zimová2, Zuzana Gregorová3, Monika Bardáčováa, Ildikó Matušiková3, Jana Moravčíkovál,}

Address(es): Ing. Eva Boszorádová, PhD.

${ }^{1}$ Institute of Plant Genetics and Biotechnology, Plant Science and Biodiversity Center Slovak Academy of Sciences, Akademická 2, P.O. Box 39A, 950 07 Nitra, Slovak Republic.

${ }^{2}$ Department of Botany and Genetics, Faculty of Natural Sciences, The Constantine Philosopher University, Nábrežie mládeže 91 , 94974 Nitra, Slovak Republic.

${ }^{3}$ Department of Ecochemistry and Radioecology, Faculty of Natural Sciences, University of SS. Cyril and Methodius in Trnava, Trnava, Nám. J.Herdu 2, 91701

Slovak Republic.

${ }^{4}$ Department of Biotechnology, Faculty of Natural Sciences, University of SS. Cyril and Methodius in Trnava, Trnava, Nám. J.Herdu 2, 917 01 Slovak Republic.

*Corresponding author: eva.boszoradova@savba.sk

doi: 10.15414/jmbfs.2019.8.5.1209-1211

\section{ARTICLE INFO}

Received 25. 5. 2018

Revised 10. 1. 2019

Accepted 15. 1. 2019

Published 1. 4. 2019

Regular article

open 2 access

\begin{abstract}
Dehydrins, one of the Late Embryogenesis Abundant (LEA) proteins, are specialized proteins related to environmental stress tolerance in plants. They are multifunctional proteins that can bind free metal ions, interact with macromolecules and specific membrane regions or participate in reduction of reactive oxygen species. Here, we report preparation of a plant transformation vector containing Arabidopsis dehydrin gene At1g54410 under the control of the strong constitutive double $d C A M V 35 S$ promoter and the selectable marker neomycin phosphotransferase gene driven by the nopaline synthase promoter. The gene At1g54410 was isolated from Arabidopsis genomic DNA by PCR approach. The resulting binary vector pND3 was introduced into the Agrobacterium tumefaciens strain LBA 4404 and verified for its stability in agrobacterial cells.
\end{abstract}

Keywords: Arabidopsis thaliana, At1g54410, dehydrins, binary vector, Agrobacterium tumefaciens

\section{INTRODUCTION}

Plants during their life cycle are constantly exposed to various environmenta stresses such as drought, high rate of salinity, low temperatures and contamination by heavy metals which negatively affect plant survival and reduce agricultural yields. To survive in such conditions, plants have to flexible respond by extensive changes of gene expressions, in biochemical signalling pathways and proteomic machinery (Ahuja et al., 2010). A part of plant response is a modulation of the cellular metabolism and production of a wide range of proteins including Late Embryogenesis Abundant (LEAs) proteins (Hong-Bo et al., 2005; Amara et al., 2014). LEA proteins are characteristic by high number of Ala, Gly, and Ser residues, and very few hydrophobic residues. According to the class nomenclature, they are divided into seven groups (Battaglia et al., 2008) Dehydrins (Group 2, Pfam PF00257) are the most characterized group of LEAs. A specific feature of dehydrins is a conserved Lys-rich 15-residue motif named as the K-segment (Campbell and Close, 1997). Along with the K-segment, dehydrins may possess some another conserved motifs such as Ser-rich Ssegment, Y-segment usually found in the N-terminus of the protein and randomly present $\varphi$-segment. Based on the presence and the arrangement of the segments $\mathrm{K}, \mathrm{Y}$ and $\mathrm{S}$, dehydrins are divided into five subclasses: $\mathrm{K}_{n}, \mathrm{SK}_{\mathrm{n}}, \mathrm{K}_{\mathrm{n}} \mathrm{S}, \mathrm{Y}_{\mathrm{n}} \mathrm{SK}_{\mathrm{n}}$ and $\mathrm{Y}_{\mathrm{n}} \mathrm{K}_{\mathrm{n}}$ (Close, 1997).

Dehydrins are multifunctional proteins that can interact with macromolecules and specific membrane regions. They can act as chaperones or antioxidants and they have an affinity to bind free metal ions (Hara et al., 2005; Koag et al., 2009; Hara, 2010). However, the molecular mechanism is still not fully understood (Hanin et al., 2011). It was supposed that dehydrins containing histidine (His) rich regions may be involved in reduction of cellular damage during stress (Svensson et al., 2000; Hara et al., 2005). The structures such as His-X3-His and His-His may play role in buffering, serve as sensors of the level of free metal ions (Hara, 2010) or may reduce reactive oxygen species (ROS) (Hara et al. 2013).

The Arabidopsis gene At1g54410 (dhl) is a KS type of dehydrin. The gene is expressed mainly in seedlings and leaves of adult plants. The weak expression was detected only in a globular stage of seed development. At later stages the expression was completely absent. It is inducible by a low temperature and a high osmotic pressure (Arabidopsis eFP database). The gene $d h l$ belongs to the group of neutral dehydrins. It contains 13 His residues, two His-3x-His and two His-His structures (Hara et al., 2011). In the presence of $\mathrm{Cu}^{2+}$ ions, it inhibits the formation of ROS (Hara et al., 2013) and restores the activity of lactate dehydrogenase (Hara et al., 2016).

In this work, we prepared a plant transformation vector pND3 containing the gene At1g54410 from Arabidopsis thaliana under the control of the double $\mathrm{d} C A M V 35 \mathrm{~S}$ promoter. The gene At1g54410 was isolated from Arabidopsis genomic DNA by PCR approach. The resulting binary vector pND3 was transformed into the Agrobacterium tumefaciens strain LBA 4404. The stability of the plasmid in agrobacterial cells was confirmed by restriction analysis after re-transformation of pND3 into Escherichia coli.

\section{MATERIAL AND METHODS}

\section{Isolation of the gene At1g54410}

The gene At1g54410 (dhl) was isolated from Arabidopsis thaliana cv. Columbia plants. The genomic DNA was isolated using the DNeasy Plant Mini Kit (Qiagen) according to the manufacture instruction. The primers P1 (forward): 5 ' GAAAGCCATGGCAGGACTCATCAAC $-3^{\prime}$ and P2 (reverse): 5' CTTCTAAAGAAACATAGATCCCAAG $-3^{\prime}$ were designed to amplify the sequence $d h 1 /$ polyA. The PCR reaction mixture of $25 \mu$ l contained $100-200 \mathrm{ng}$ of DNA template, 20 pmol of each primer, 0,2 mmol. $1^{-1} \mathrm{dNTPs}, 1 \times$ PCR buffer 2,5 mmol. $\mathrm{I}^{-1} \mathrm{MgCl}_{2}$ and 1U FIREPol Taq DNA polymerase (Solid Biodyne, Estonia). The PCR reaction was performed at $95^{\circ} \mathrm{C}$ for $4 \mathrm{~min}$, followed by 35 cycles of $95^{\circ} \mathrm{C}$ for 45 seconds, $63^{\circ} \mathrm{C}$ for 45 seconds and $72{ }^{\circ} \mathrm{C}$ for 2 minutes and the last step at $72^{\circ} \mathrm{C}$ for $10 \mathrm{~min}$. The PCR amplicon was isolated using the QIAquick Gel Extraction Kit (Qiagen) according to the manufacturer's instructions and commercially sequenced.

\section{Vector construct}

The PCR amplicon was cloned into the pGEM-T ${ }^{\circledR}$ Easy plasmid (Promega) to yield the pND. The sequence $d h 1 /$ polyA from the pND was ligated as an EcoRIEcoRI into the cloning vector pBSK+ to create pND1. The plasmid pND2 was prepared by ligation of the $d C A M V 35 S$ promoter as HindIII-NcoI fragment from 
the plasmid pBS4 and the sequence dhl/polyA as NcoI-ClaI fragment from the pND1 into the plasmid pUN (Vaculková et al., 2007). The plant transformation vector pND3 was obtained by ligation of the $d C A M V 35 S / d h 1 / p o l y A$ sequence as $X b a \mathrm{I}-E c o \mathrm{RI}$ fragment into the binary vector pBinPlus (Van Engelen, 1995). The resulting vector pND3 was introduced into Agrobacterium tumefaciens strain LBA 4404 using "triparental matting" method (Matzke and Matzke, 1986).

\section{Verification of the stability of the pND3 in Agrobacterium tumefaciens}

The plasmid pND3 was isolated using the QIAprep Spin Miniprep Kit (Qiagen) according to the manufacturer's instructions. Subsequently, the pND3 was retransformed into E. coli. The individual clones were isolated using the QIAprep Spin Miniprep Kit (Qiagen) and subjected to the restriction analysis.

\section{RESULTS AND DISCUSSION}

Dehydrins are thermostable and hydrophilic proteins that are accumulate not only during plant growth and development but also during abiotic stresses such as low temperature, dehydration or osmotic pressure (Allagulova et al., 2003). Using plant transgenosis, at least 20 dehydrins from different plant species such as barley, pea or maize were introduced into different plant species and studied for their role in tolerance against various abiotic stresses (Peng $\boldsymbol{e t}$ al., 2008; Xu $\boldsymbol{e t}$ al., 2008; Hara et al., 2011; Ochoa-Alfaro et al., 2012; Hill et al., 2016). These studies proved on the role of dehydrins in abiotic stress tolerance of transgenic plants. For example, the expression of the dehydrin RcDhn5 from Rhododendron catawbiense contributed to freezing tolerance of transgenic Arabidopsis thaliana plants (Peng et al., 2008) or the expression of the dehydrin BjDHN2 from Brassica juncea increased heavy metal tolerance of transgenic plants Nicotiana tabacum (Xu et al., 2008).

Using transgenic approach we aimed to study the role of the dehydrin gene Atlg54410 (dhl) in heavy metal tolerance. For this, using the techniques of recombinant DNA we prepared the plant transformation vector $\mathrm{pND} 3$. The TDNA of resulting plasmid pDN3 contained the $d h 1$ gene under the control of the $d C A M V 35 S$ promoter and the selectable neomycin phosphotransferase gene (nptII) driven by the nos promoter. The cloning strategy is given in Figure 1.

We designed a set of specific primers P1/P2 that were expected to amplify an 833 bp fragment of the sequence dhl/polyA. The identity of the amplified sequence we confirmed by restriction analysis (data not shown) and by sequencing. The sequence alignment of the fragment P1-P2 with the sequence of the At1g54410 is given in Figure 2. The sequence dhl/polyA was isolated from the plasmid pND as an $E c o$ RI-EcoRI fragment and ligated into the cloning vector $\mathrm{pBSK}+$ to yield the plasmid pND1. Subsequently, the sequence dhl/polyA as an NcoI-ClaI fragment sequence of the pND1 and the sequence of the $d C A M V 35 S$ promoter as a HindIII-NcoI fragment of the plasmid BS4 were ligated into the plasmid pUN. Then, the expression unit consisting of sequence $d 35 \mathrm{~S} /$ dhl/polyA was cloned into the binary vector pBinPlus. The T-DNA of the pBinPlus contains the plant selectable marker nptII gene that inactivates by phosphorylation a range of aminoglycoside antibiotics. It allows regeneration of transgenic plant cells under selection pressure of antibiotics such as kanamycin or geneticin (Bevan $\boldsymbol{e t}$ al., 1983)

The identity of the plasmid pND3 was confirmed by restriction analysis. The position of the restriction endonucleases in the T-DNA-pDN3 and the expected fragment sizes are given in Figure 3a. The results of restriction analysis are shown in Figure 3b.

Previously, we observed that some T-DNA sequences may exhibit instability features in Agrobacterium (Vaculková et al., 2007). Thus, we tested the stability of the plasmid pND3 in A. tumefaciens LBA 4404. After re-transformation of the plasmid pND3 into $E$. coli, individual clones were digested with the restriction endonucleases $B g l I I$ and $C l a I$. The position and expected sizes of the restriction fragments are given in Figure 4a. Restriction analysis of all (30) clones demonstrated correct restriction pattern. An example of restriction analysis is shown in Figure 4b.
pND1

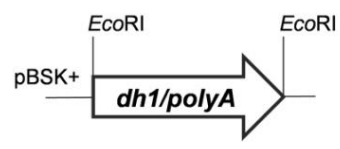

pND2

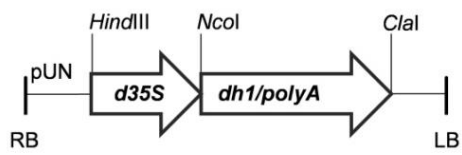

pND3

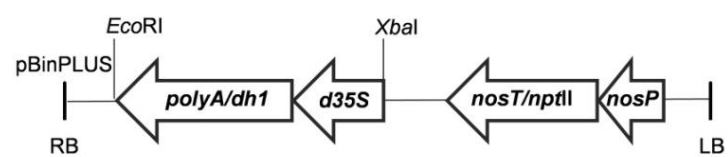

Figure 1 Cloning strategy used to prepare the plant transformation vector pND3 The restriction enzymes used in individual cloning steps are indicated. $d 35 S-$ double $C A M V 35 S$ promoter, $d h 1$ - dehydrin gene, polyA - poly sequence of gene $d h 1$, nosT - nos terminator, nptII - neomycin phosphotransferase gene, nos $P$ - nos promoter.

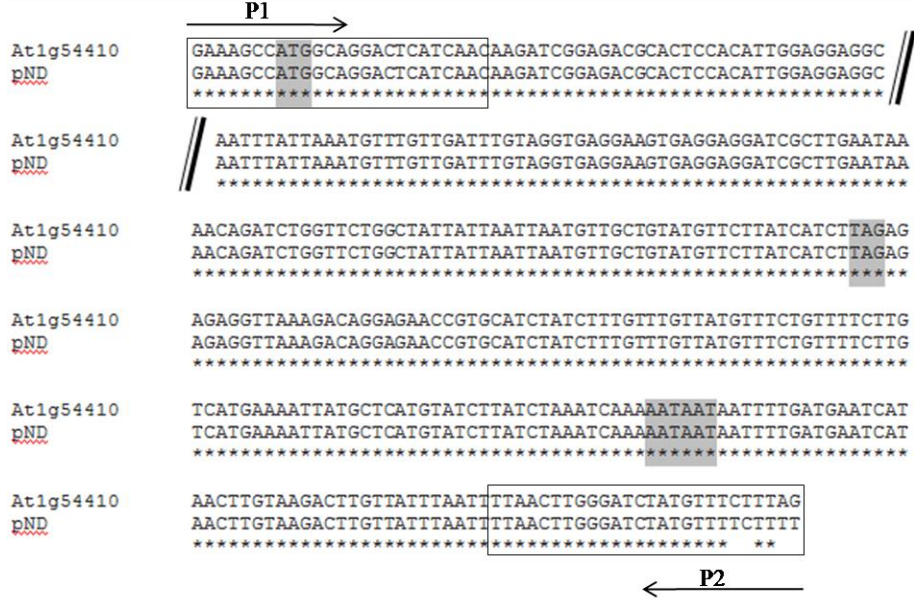

Figure 2 The alignment of the P1-P2 sequence (pND) with the sequence of the At1g54410 gene. The alignment was generated using CLUSTAL OMEGA program. Nucleotides which are conserved in the sequences aligned are marked by asterisks. Dashes show the position of the sequences polyA (AATAAT), start codon (ATG) and the stop codon (TAG). The sequence of the primers P1 and P2 are in the boxes. The arrows outline their position.

a)

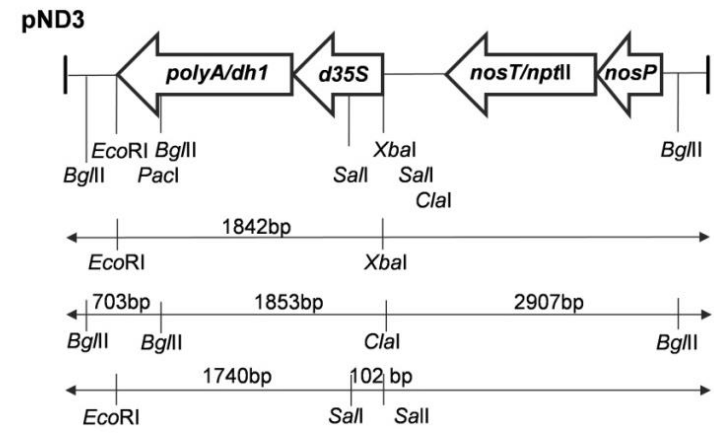

b)

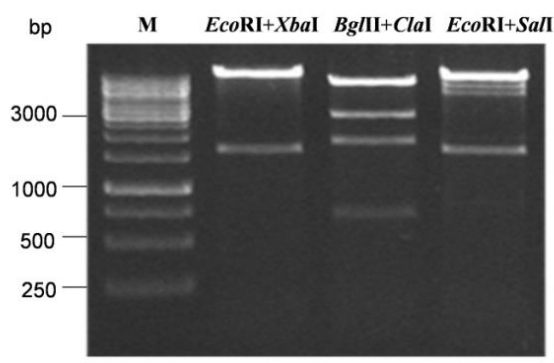

Figure 3 Restriction map and restriction analyses of the T-DNA-pND3. a) TDNA region of the plant transformation vector pND3. The position of restriction 
endonucleases and expected sizes of DNA fragments are indicated. b) Photograph of an ethidium bromide-stained $1 \%(\mathrm{w} / \mathrm{v})$ agarose gel. The lane $\mathrm{M}$ contains $1 \mathrm{~kb}$ DNA ladder (Fermentas) as a size marker, lanes 1-3 contain the plasmid pND3 digested with the restriction enzymes EcoRI+XbaI, BglII+ClaI and EcoRI+Sall.

a)

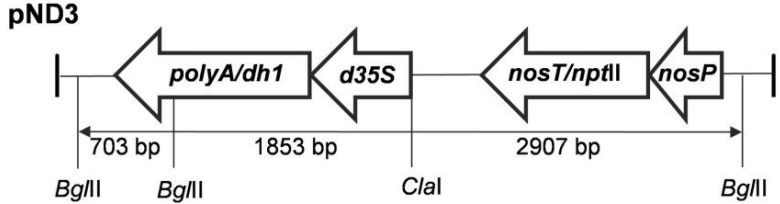

b)

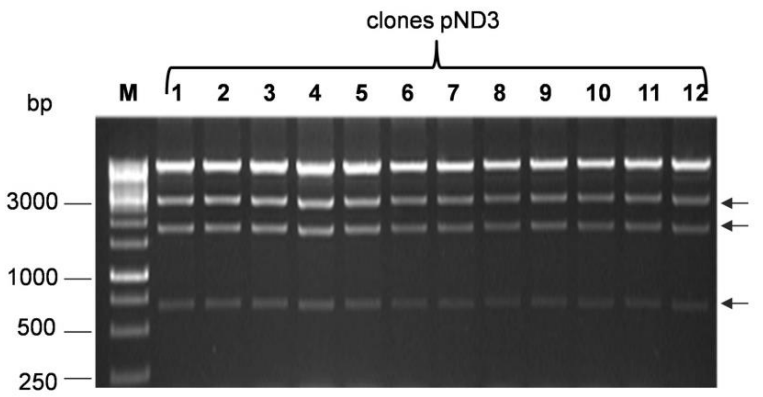

Figure 4 Restriction analyses of the T-DNA-pND3 after re-transformation of the plasmid into E. coli. a) The T-DNA region of the pND3 with the position of the restriction endonucleases $B g l \mathrm{II}$ and $C l a \mathrm{I}$. b) Photograph of an ethidium bromidestained $1 \%(\mathrm{w} / \mathrm{v})$ agarose gel. The lane $M$ contains $1 \mathrm{~kb}$ DNA ladder (Fermentas) as a size marker, the lanes 1-12 contain individual clones of the pND3 digested with the restriction enzymes $B g l I I$ and ClaI.

\section{CONCLUSION}

With the aim to study the role of the dehydrin gene At1g54410 from A. thaliana in tolerance against selected types of abiotic stresses using plant transgenosis, we prepared the plant transformation vector pND3. The T-DNA-pND3 contained the gene At1g54410 under the control of the constitutive $\mathrm{d} C a M V 35 \mathrm{~S}$ promoter and the selectable marker $n p t I I$ gene. The plant transformation vector pND3 has been shown to be stable in A. tumefaciens LBA 4404. In future, A. tumefaciens LBA 4404 carrying the binary vector pND3 will be used in tobacco transformation.

Acknowledgments: This work was funded by the Slovak Grant Agency VEGA project 2/0035/17 and by the University Grant Agency UKF UGA VIII/26/2018

\section{REFERENCES}

AHUJA, I., DE VOS, R. CH., BONES, A. M., HALL, R. D. 2010. Plant molecular stress responses face climate change. Trends in Plant Sciences 15(12), 664-674. https://doi.org/10.1016/j.tplants.2010.08.002

ALLAGULOVA, C. R., GIMALOV, F. R., SHAKIROVA, F. M., VAKHITOV, V. A. 2003. The plant dehydrins: Structure and putative functions. BiochemistryMoscow, 68 (9), 945-951. https://doi.org/10.1023/A:1026077825584

AMARA, I., ZAIDI, I., MASMOUDI, K., LUDEVID, M. D., PAGÈS, M. GODAY, A., BRINI, F. 2014. Insights into late embryogenesis abundant (LEA) proteins in plants: from structure to the functions. American Journal of Plant Sciences 5(22), 3440-3455. https://dx.doi.org/10.4236/ajps.2014.522360

BATTAGLIA, M., OLVERA-CARRILLO, Y., GARCIARRUBIO, A., CAMPOS, F., COVARRUBIAS, A. A. 2008. The enigmatic LEA proteins and other hydrophilins. Plant Physiology 148, 6-24 https://doi.org/10.1104/pp.108.120725

BEVAN, M. W., FLAVELL, R. B., CHILTON, M. D. 1983. A chimaeric antibiotic-resistance gene as a selectable marker for plant-cell transformation. Nature 304(5922), 184-187. https://doi.org/10.1038/304184a0

CAMPBELL, S. A., CLOSE, T. J. 1997. Dehydrins: genes, proteins, and associations with phenotypic traits. New Phytologist 137(1), 61-74. https://doi.org/10.1046/j.1469-8137.1997.00831.x

CLOSE, T. J. 1997. Dehydrins: a commonality in the response of plants to dehydration and low temperature. Physiologia Plantarum 100(2), 291-296 https://doi.org/10.1111/i.1399-3054.1997.tb04785.x

HANIN, M., BRINI, F., EBEL, C., TODA, Y., TAKEDA, S., MASMOUDI, K 2011. Plant dehydrins and stress tolerance versatile proteins for complex mechanisms. Plant Signaling \& Behavior 6(10), 1503-1509. https://doi.org/10.4161/psb.6.10.17088

HARA, M. 2010. The multifunctionality of dehydrins An overview. Plant Signaling \& Behavior 5(5), 503-508. https://doi.org/10.4161/psb.11085

HARA, M., FUJINAGA, M., KUBOI, T. 2005. Metal binding by citrus dehydrin with histidine-rich domains. Journal of Experimental Botany 56(420), 26952703. https://doi.org/10.1093/jxb/eri262

HARA, M., KONDO, M., KATO, T. 2013. A KS-type dehydrin and its related domains reduce $\mathrm{Cu}$-promoted radical generation and the histidine residues contribute to the radical-reducing activities. Journal of Experimental Botany 64(6), 1615-1624. https://doi.org/10.1093/jxb/ert016

HARA, M., MONNA, S., MURATA, T., NAKANO, T., AMANO, S. NACHBAR, M., WATZIG, H. 2016. The Arabidopsis KS-type dehydrin recovers lactate dehydrogenase activity inhibited by copper with the contribution of His residues Plant Science 245, 135-142. https://doi.org/10.1016/j.plantsci.2016.02.006

HARA, M., SHINODA, Y., KUBO, M., KASHIMA, D., TAKAHASHI, I., KATO, T., HORIIKE, T., KUBOI, T. 2011. Biochemical characterization of the Arabidopsis KS-type dehydrin protein, whose gene expression is constitutively abundant rather than stress dependent. Acta Physiologiae Plantarum 33(6), 2103 2116. https://doi.org/10.1007/s11738-011-0749-1

HILL, W., JIN, X. L., ZHANG, X. H. 2016. Expression of an arctic chickweed dehydrin, CarDHN, enhances tolerance to abiotic stress in tobacco plants. Plant Growth Regulation 80(3), 323-334. https://doi.org/10.1007/s10725-016-0169-8 HONG-BO, S., ZONG-SUO, L., MING-AN, S. (2005). LEA proteins in higher plants: structure, function, gene expression and regulation. Colloid Surface B, 45 (3-4), 131-135. https://doi.org/10.1016/j.colsurfb.2005.07.017

KOAG, M. C., WILKENS, S., FENTON, R. D., RESNIK, J., VO, E., CLOSE, T. J. 2009. The K-Segment of Maize DHN1 Mediates Binding to Anionic Phospholipid Vesicles and Concomitant Structural Changes. Plant Physiology 150(3), 1503-1514. https://doi.org/10.1104/pp.109.136697

MATZKE, A. J. M., MATZKE, M. A. 1986. A set of novel Ti plasmid-derived vectors for the production of transgenic plants. Plant Molecular Biology 7(5), 357-365. https://doi.org/10.1007/BF00032565

OCHOA-ALFARO, A. E., RODRIGUEZ-KESSLER, M., PEREZ-MORALES, M. B., DELGADO-SANCHEZ, P., CUEVAS-VELAZQUEZ, C. L., GOMEZ ANDURO, G., JIMENEZ-BREMONT, J. F. 2012. Functional characterization of an acidic SK3 dehydrin isolated from an Opuntia streptacantha cDNA library. Planta 235(3), 565-578. https://doi.org/10.1007/s00425-011-1531-8

PENG, Y. H., REYES, J. L., WEI, H., YANG, Y. I., KARLSON, D., COVARRUBIAS, A. A., KREBS, S. L., FESSEHAIE, A., ARORA, R. 2008 RcDhn5, a cold acclimation-responsive dehydrin from Rhododendron catawbiense rescues enzyme activity from dehydration effects in vitro and enhances freezing tolerance in RcDhn5-overexpressing Arabidopsis plants Physiologia Plantarum 134(4), 583-597. https://doi.org/10.1111/j.13993054.2008.01164.x

SVENSSON, J., PALVA, E. T., WELIN, B. 2000. Purification of recombinan Arabidopsis thaliana dehydrins by metal ion affinity chromatography. Protein $\begin{array}{llll}\text { Expression and } & \text { 20(2), } & \text { 169-178 }\end{array}$ https://doi.org/10.1006/prep.2000.1297

VACULKOVA, E., MORAVCIKOVA, J., MATUSIKOVA, I., BAUER, M., LIBANTOVA, J. 2007. A modified low copy number binary vector pUN for Agrobacterium-mediated plant transformation. Biologia Plantarum 51(3), 538540. https://doi.org/10.1007/s10535-007-0116-7

VANENGELEN, F. A., MOLTHOFF, J. W., CONNER, A. J., NAP, J. P., PEREIRA, A., STIEKEMA, W. J. 1995. pBINPLUS - an improved plan transformation vector based on pBIN19. Transgenic Research 4(4), 288-290. https://doi.org/10.1007/BF01969123

XU, J., ZHANG, Y. X., WEI, W., HAN, L., GUAN, Z. Q., WANG, Z., CHAI, T. Y. 2008. BjDHNs confer heavy-metal tolerance in plants. Molecular Biotechnology 38(2), 91-98. https://doi.org/10.1007/s12033-007-9005-8 